\title{
HUBUNGAN INTERPRETASI WHO (WORLD HEALTH ORGANIZATION) ANTROPOMETRI Z-SCORE DAN INFEKSI KECACINGAN PADA ANAK USIA 36 - 60 BULAN DI KOTA LHOKSEUMAWE
}

\author{
Mardiati $^{1}$, Fury Maulina ${ }^{2}$, Muhammad Sayuti $^{3}$ \\ ${ }^{1)}$ Bagian Ilmu Kesehatan Anak, Fakultas Kedokteran, Universitas Malikussaleh \\ ${ }^{2)}$ Bagian Ilmu Kesehatan Masyarakat, Fakultas Kedokteran, Universitas Malikussaleh \\ ${ }^{3)}$ Bagian Ilmu Bedah, Fakultas Kedokteran, Universitas Malikussaleh \\ Corresponding Author: mardiati8143@yahoo.co.id
}

\begin{abstract}
Abstrak
Status gizi pada anak masih menjadi masalah utama di Indonesia. Metode penentuan status gizi yang sering digunakan adalah dengan interpretasi WHO antropometri zscore. Selain penentuan status gizi, sangat penting mengetahui infeksi yang dialami oleh anak, salah satunya yaitu infeksi kecacingan. Penelitian ini bertujuan untuk mengetahui karakteristik dan hubungan interpretasi WHO antropometri z-score berdasarkan Berat Badan (BB) menurut usia dan infeksi kecacingan pada anak usia 36 - 60 bulan di Posyandu Pusong Kota Lhokseumawe. Penelitian ini merupakan deskriptif analitik dengan rancangan cross sectional. Sampel penelitian adalah anak di Gampong Pusong yang memenuhi kriteria inklusi dan eksklusi. Interpretasi menggunakan software WHO Anthro serta infeksi kecacingan dilakukan dengan pemeriksaan feses dengan teknik direct thin smear feces menggunakan mikroskop. Data dianalisis secara secara univariat dan bivariat. Hasil penelitian didapatkan anak usia 36-47 bulan sebanyak 44,7\% serta usia 48 - 60 bulan sebesar 55.3\%; 57,9\% adalah perempuan, dengan rata - rata berat badan adalah $14 \pm 2.07 \mathrm{~kg}$ dan rata - rata tinggi badan adalah $92 \pm 6,71 \mathrm{~cm}$. Interpretasi WHO antropometri $z$-score berdasarkan BB menurut usia diperoleh sebesar $60,5 \%$ dengan status gizi baik, 39,5\% dengan status gizi kurang, serta tidak ditemukan gizi lebih dan gizi buruk. Sebanyak 26,3\% positif mengalami infeksi kecacingan dengan $80 \%$ mengalami infeksi oleh cacing Ascaris lumbricoides serta 20\% mengalami infeksi campuran oleh cacing Ascaris lumbricoides dan Trichuris trichiura. Hasil analisis bivariat didapatkan tidak terdapat hubungan antara interpretasi WHO antropometri z score berdasarkan BB menurut usia dengan infeksi kecacingan pada anak usia 36 - 60 bulan di Posyandu Gampong Pusong Kota Lhokseumawe.
\end{abstract}

Kata Kunci : z-score, antropometri, WHO, infeksi kecacingan 


\title{
Relationship of Interpretation of Z-Score Anthropometry WHO and Worm Infection in Children Aged 36 - 60 Months in the City of Lhokseumawe
}

\begin{abstract}
The nutritional status of children is still a major problem in Indonesia. The most frequently used method in determination of nutritional status in children is Z-Score Anthropometry WHO interpretation. In addition, it is important to understand the infection diseases in children. One of them is worm infection. This study aimed to examine respondent characteristics and relationship of Interpretation of Z-Score Anthropometry WHO based on body weight according to age and worm infection in children aged 36 - 60 months at Posyandu Pusong in the City of Lhokseumawe. This study was a descriptive analytic with cross sectional design. Samples were children in Gampong Pusong who met the inclusion and exclusion criteria. Interpretation for nutritional status used WHO Anthro software, meanwhile examination of worm infection was conducted by feces examining with a direct thin smear technique used microscope. Data were analyzed by univariate and bivariate analysis. The results showed that $55.3 \%$ children aged $48-60$ months; $57.9 \%$ were girls, with mean of body weight were $14 \pm 2.07 \mathrm{~kg}$ and mean of height were $92 \pm 6.71 \mathrm{~cm}$. Additionally, Interpretation of Z-Score Anthropometry WHO based on weight according to age were good nutritional status $(60.5 \%)$ and low nutritional status $(39.5 \%)$. Meanwhile, over nutrition and malnutrition was not found. Total of $26.3 \%$ were positive for worm infection with 80\% experiencing Ascaris lumbricoides infections and 20\% experiencing a mix of Ascaris lumbricoides and Trichuris trichiura infections. Further, bivariate analysis showed that there was no relationship of Z-Score Anthropometry WHO based on body weight according to age and worm infections in children aged $36-60$ months at Posyandu Gampong Pusong, City of Lhokseumawe.
\end{abstract}

Keywords: z-score, anthropometry, WHO, worm infection

\section{PENDAHULUAN}

Perserikatan Bangsa-Bangsa tahun 2011, memperkirakan bahwa 100 juta anak kekurangan berat badan. Beberapa prevalensi malnutrisi tertinggi terlihat di Asia, khususnya di wilayah selatan-tengah (1). Salah satu indikator yang umumnya digunakan untuk menilai kesehatan anak dilakukan melalui penentuan status gizi. Penentuan status gizi salah satunya dilakukan berdasarkan pemeriksaan antropometri. Grafik pertumbuhan yang digunakan sebagai acuan ialah grafik WHO 2006 (2). Pada hasil pemeriksaan antropometri, data berat badan dan tinggi badan akan dikonversikan ke dalam $z$-score untuk penentuan status gizi. Z-score yang digunakan berdasarkan indeks berat badan menurut usia $(\mathrm{BB} / \mathrm{U})$, indeks tinggi/panjang badan menurut umur $(\mathrm{TB} / \mathrm{U}$ atau $\mathrm{PB} / \mathrm{U}$ ) dan indeks berat badan menurut tinggi/panjang badan (BB/TB atau BB/PB). Standar $z$-score menggunakan standar antropometri dari Peraturan Menteri Kesehatan tahun 2010 (3). Selain penentuan status gizi anak yang sangat penting diketahui, sejumlah kondisi ternyata dapat mempengaruhi kesehatan anak, salah satunya infeksi.

Infeksi kecacingan merupakan salah satu masalah kesehatan masyarakat di 
Indonesia yang sering dijumpai (4) namun paling sering ditemukan pada anak usia 3 - 5 tahun (5). Infeksi kecacingan akan mempengaruhi pemasukan (intake), pencernaan (digestif), penyerapan (absorpsi), dan metabolisme makanan. Secara kumulatif infeksi kecacingan dapat menimbulkan kekurangan gizi berupa kalori dan protein, serta kehilangan darah yang berakibat menurunnya daya tahan tubuh dan menimbulkan gangguan tumbuh kembang anak (6).

Prevalensi Infeksi kecacingan yang disebabkan STH secara global pada tahun 2014 yaitu 24\% dari populasi penduduk dunia, sedangkan jumlah infeksi STH di Asia Tenggara adalah sebanyak 610,5 juta orangdan esitimasi prevalensi nasional Indonesia sebanyak 20-50\% (7). Infeksi yang terjadi pada saluran cerna dapat memberikan pengaruh terhadap status gizi, salah satunya yaitu infeksi kecacingan yang diakibatkan oleh kelompok cacing Soil-Transmitted Helminths (STH) yaitu cacing gelang (Ascaris lumbricoides), cacing cambuk (Trichuris trichiura), dan cacing tambang (Ancylostoma duodenale dan Necator americanus). Anak dengan infeksi cacing ini akan mengalami malabsorpsi, inflamasi, dan penurunan asupan makan karena nafsu makan yang kurang saat infeksi (8).

World Health Organization (WHO) memperkirakan lebih dari 1 milyar penduduk terinfeksi Ascaris, 740 juta terinfeksi cacing tambang, 795 juta terinfeksi trichuris (9). Prevalensi tertinggi ditemukan di negara-negara yang sedang berkembang. Prevalensi infeksi kecacingan di Indonesia masih tinggi, yaitu 45-65\%. Wilayah-wilayah tertentu dengan sanitasi yang buruk, prevalensi kecacingan dapat mencapai 80\% (10). Aceh merupakan provinsi dengan peringkat kedua tertinggi infeksi kecacingan di Indonesia, dengan prevalensi 59,2\% (11). Pemerintah Indonesia menetapkan program penanggulangan cacingan dengan target reduksi cacingan berupa penurunan prevalensi kecacingan sampai dengan angka di disetiap daerah kabupaten/ kota.

\section{METODE}

\section{Desain}

Jenis penelitian ini adalah deskriptif analitik dengan rancangan cross sectional. Penelitian ini dilakukan di Posyandu Gampong Pusong Kota Lhokseumawe dan Laboratorium Parasitologi Fakultas Kedokteran Universitas Malikussaleh.

\section{Populasi dan sampel}

Populasi dalam penelitian ini adalah seluruh anak Kota Lhokseumawe. Sampel penelitian adalah anak di Gampong Pusong yang memenuhi kriteria inklusi dan eksklusi. Kriteria inklusinya adalah: a) orang tua bersedia menjadi responden; b) anak berusia 36 - 60 bulan, sementara kriteria eksklusinya adalah anak yang telah minum obat cacing kurang dari enam bulan.

\section{Teknik pengambilan sampel}


Teknik pengambilan sampel dalam penelitian ini adalah menggunakan teknik non probability sampling dengan cara purposive sampling. Besar sampel dalam penelitian ini adalah seluruh jumlah populasi yang memenuhi kriteria inklusi dan eksklusi sebanyak 38 orang.

\section{Sumber data dan instrumen}

Data primer yang diperoleh pada penelitian ini mengalami tahapan: 1) editing; 2) coding; 3) tabulating: dan 4) presenting.

\section{Analisis data}

Analisis data menggunakan analisis univariat dan bivariat (chi-square).

\section{HASIL PENELITIAN}

\section{Karakteristik responden}

Karakteristik anak usia 36 - 60 bulan di Posyandu Gampong Pusong Kota Lhokseumawe dalam penelitian ini dikelompokkan menurut usia, jenis kelamin, ratarata berat dan tinggi badan. Karakteristik responden dapat dilihat pada tabel1. Diperoleh hasil, lebih dari setengah responden adalah berusia 48 - 60 bulan (55.3\%), dan setengahnya adalah perempuan, dengan rata - rata berat badan adalah $14 \mathrm{~kg}$ dan rata rata tinggi badan adalah $92 \mathrm{~cm}$.

Tabel 1 KarakteristikRespondenPenelitian( $(\mathrm{n}=38)$

\begin{tabular}{lcc}
\hline \multicolumn{1}{c}{ Karakteristik } & n & Persentase (\%) \\
\hline Usia & & \\
36-47 bulan & 17 & 44,7 \\
48-60 bulan & 21 & 55,3 \\
Jeniskelamin & & \\
$\quad$ Laki-laki & 16 & 42,1 \\
$\quad$ Perempuan & 22 & 57,9 \\
Rata-rata berat badan (kg) & $14 \pm 2,07$ & \\
Rata-rata tinggi badan (cm) & $92 \pm 6,71$ & \\
\hline
\end{tabular}

\section{Interpretasi WHO Z-Score MenurutAntropometri}

Tabel 2 Interpretasi WHO $z$-scoreberdasarkan BB menurutusia(n=38)

\begin{tabular}{lcc}
\hline \multicolumn{1}{c}{ WHO Z-score } & n & Persentase (\%) \\
\hline Z score $>+2$ SD (gizi lebih) & 0 & 0 \\
-2 SD $<$ Z-score $<+2$ SD (gizi baik) & 23 & 60,5 \\
-3 SD $<$ Z-score $<-2$ SD (gizi kurang) & 15 & 39,5 \\
Z- score $<-3$ SD (gizi buruk) & 0 & 0 \\
\hline
\end{tabular}

Tabel 2, menunjukkan bahwa sebagian besar responden memiliki gizi baik (60.5\%), gizi kurang sebanyak 39,5\% serta tidak ditemukan gizi lebih dan gizi buruk. 


\section{Infeksi Kecacingan}

Infeksi kecacingan pada responden ditunjukkan pada tabel 3.

Tabel 3 Infeksi kecacingan pada responden $(n=38)$

\begin{tabular}{lcc}
\hline & n & Persentase (\%) \\
\hline Infeksi kecacingan & & \\
$\quad$ Negatif & 28 & 73,7 \\
Positif & 10 & 26,3 \\
Identifikasi cacing yang menginfeksi: & & \\
Ascaris lumbricoides & 8 & 80 \\
Ascaris lumbricoides + Trichuris trichiura & 2 & 20 \\
\hline
\end{tabular}

Tabel 3 menunjukkan bahwa 10 dari 38 responden mengalami infeksi kecacingan yang sebagian besar diinfeksi oleh Ascaris lumbricoides.

\section{Hubungan Interpretasi Z-Score Berdasarkan BB Menurut Usia dengan Infeksi}

\section{Kecacingan}

Tabel 4 menunjukkan hubungan interpretasi z-score berdasarkan BB menurut usia dengan infeksi kecacingan $(n=38)$

\begin{tabular}{lccccc}
\hline \multirow{4}{*}{$\begin{array}{c}\text { Infeksi } \\
\text { kecacingan }\end{array}$} & $\begin{array}{c}\text { Z score }> \\
+2 \mathrm{SD} \\
\text { (gizi lebih) }\end{array}$ & $\begin{array}{c}-2 \mathrm{SD}<\mathrm{Z}- \\
\text { score }<+2 \mathrm{SD} \\
\text { (gizi baik) }\end{array}$ & $\begin{array}{c}-3 \mathrm{SD}<\mathrm{Z}- \\
\text { score }<-2 \mathrm{SD} \\
\text { (gizi kurang) }\end{array}$ & $\begin{array}{c}<- \text { - score } \\
\text { (gizi buruk) }\end{array}$ & $\begin{array}{c}p \\
\text { value }\end{array}$ \\
\cline { 2 - 6 } Negatif & 0 & 23 & 5 & 0 & 0,152 \\
Positif & 0 & 10 & 0 & 0 & \\
\hline
\end{tabular}

Tabel 4 memperlihatkan hasil analisis bivariat menggunakan uji chi-square, didapatkan bahwa $\mathrm{H}_{0}$ diterima dan Ha ditolak, yang menunjukkan bahwa tidak terdapat hubungan antara interpretasi Z-score berdasarkan BB menurut usia.

\section{PEMBAHASAN}

Kejadian infeksi terbanyak adalah Ascaris Lumbricoides kemudian campuran cacing Ascaris lumbricoides dan Trichuris trichiura. Hal ini sesuai dengan penelitian yang dilakukan pada anak Balita di Kampung Keputih Kecamatan Sukolilo juga menunjukkan bahwa frekuensi infeksi kecacingan tinggi pada anak, yaitu Ascaris Lumbricoides(71,18\%), Trichuris Trichiura (26,42\%) dan Enterobius Vemicularis $(13,92 \%)(12)$.

Menurut World Health Organization (WHO), tingkat infeksi kecacingan menunjukkan indeks sanitasi di masyarakat. Kecacingan di negara berkembang seperti 
Indonesia memang tidak cepat menimbulkan kematian atau case fatality rate (CFR) rendah, tetapi dapat mengganggu tumbuh kembang manusia terutama anak-anak. Kecacingan ditularkan melalui kontaminasi tanah maupun air akibat hygiene dan sanitasi yang buruk. Hal ini dapat diperburuk dengan perilaku yang tidak sehat. Telur cacing Ascaris dan trichuris banyak terdapat di daerah iklim tropis dan hidup di tanah liat(13).

Selain keadaan tanah, iklim, suhu yang sesuai, keadaan endemik juga dipengaruhi oleh jumlah telur yang hidup dan masuk ke dalam hospes. Semakin banyak telur yang ditemukan pada sumber kontaminasi maka semakin tinggi pula derajat endemik suatu daerah (14). Cacing betina Ascaris lumbricoides dapat mengeluarkan telur 100.000200.000 butir perhari ditanah, jadi apabila telur tersebut keluar bersama tinja dan menjadi infektif kemudian terkontaminasi maka seseorang tersebut dapat terinfeksi cacing Ascaris lumbricoides (15).

Kontaminasi Ascaris lumbricoides biasanya diikuti pula dengan kontaminasi Trichuris trichiura. Hal ini disebabkan oleh penyebaran Ascaris dan Tricuris mempunyai pola yang hampir sama baik itu suhu optimum maupun waktu perkembangan di tanah. Prevalensi Trichuris trichiura biasanya lebih rendah jika dibandingkan Ascaris lumbricoides (16). Pada penelitian ini tidak ditemukan infeksi kecacingan jenis cacing tambang, hal ini dikarenakan prevalensi cacing tambang lebih tinggi ditemukan di daerah perkebunan (karet, kopi) serta dipertambangan (17).

Berdasarkan hasil analisis data ditemukan tidak terdapat hubungan antara kecacingan dan status gizi anak usia $36-60$ bulan berdasarkan indeks BB/U dengan $p$ value sebesar $0,152(\mathrm{p}>\alpha=0,05)$. Berdasarkan hasil yang ada didapatkan tidak ada anak yang yang berstatus gizi buruk dan gizi lebih. Anak dengan gizi kurang tidak ada yang positif kecacingan. Terdapat 10 anak yang berstatus gizi baik yang positif terinfeksi cacing. Penelitian ini menunjukkan bahwa yang positif terinfeksi kecacingan adalah anak dengan status gizi baik. Hal ini bisa disebabkan oleh faktor - faktor yang dapat menyebabkan infeksi kecacingan pada anak. Penelitian yang dilaksanakan pada anak balita di Kampung Keputih Kecamatan Sukolilo Surabaya pada tahun 2010, didapatkan bahwa ada beberapa faktor yang berhubungan dengan kejadian kecacingan pada anak dibawah lima tahun (balita) antara lain adalah keberadaan sarana sanitasi (jamban), kebiasaan buang air besar (BAB), masih adanya lantai tanah, kebiasaan cuci tangan setelah $\mathrm{BAB}$, dan pengetahuan ibu tentang kecacingan (12).

\section{KESIMPULAN}

1. Distribusi infeksi kecacingan berdasarkan jenis kelamin, didapatkan perempuan lebih tinggi dibandingkan dengan laki-laki. Frekuensi infeksi kecacingan berdasarkan usia, didapatkan usia $36-60$ bulan lebih banyak terinfeksi kecacingan, dengan rata- rata berat badan $14 \pm 2.07$ dan rata - rata tinggi badan 92 \pm 6.71 .

2. Frekuensi kejadian infeksi kecacingan pada anak usia 36 - 60 bulan yang terbanyak adalah Ascaris lumbricoides dan sedikit yang mengalami kejadian 
infeksi campuran cacing Ascaris dan Trichuris trichiura.

3. Interpretasi WHO z-score menurut antropometri berdasarkan BB menurut usia, memperlihatkan bahwa anak terlihat lebih banyak memiliki gizi baik.

4. Tidak terdapat hubungan antara interpretasi WHO antropometri z-score berdasarkan BB menurut usia, dengan infeksi kecacingan pada anak usia 36-60 bulan di Posyandu Gampong Pusong Kota Lhokseumawe.

\section{REFERENSI}

1. The Friesland Campina Institute. Nutritional status of children aged 0.5 to 12 years in Indonesia, Malaysia, Thailand and Vietnam: South East Asia Nutrition Survey (SEANUTS) results. [Internet]. 2019. Available from: https://www.frieslandcampinainstitute.asia/health/child-nutrition/nutritional-statuschildren-aged-0-5-12-years-indonesia-malaysia-thailand-vietnam-south-east-asianutrition-survey-seanuts-results/

2. Unit Kerja Koordinasi Nutrisi dan Penyakit Metabolik. Rekomendasi asuhan nutrisi pediatrik. Dalam: Sjarif DR, Nasar SS, Devaera Y, Tanjung C, penyunting. Buku asuhan nutrisi pediatrik. Jakarta: Ikatan Dokter Anak Indonesia, 2011. h.1-13.

3. Kementrian Kesehatan RI .Keputusan Menteri Kesehatan Republik Indonesia Nomor 1995/MEKES/SK/XII/210 Tentang Standar Antropometri Penilaian Status Gizi Anak. Jakarta. 2010.

4. Mardiana, Djarismawati. 2008. Prevalensi cacing usus pada murid SD wajib belajar pelayanan gerakan terpadu pengentasan kemiskinan daerah kumuh di wilayah DKI Jakarta. Jurnal Ekologi Kesehatan, 7(2): 769-774.

5. Waris, Lukman dan Nita, Rahayu. 2009. Distribusi Parasit Pencernaan Di Sekolah Dasar Negeri Miawa Kecamatan Piani Kabupaten Tapin Provinsi Kalimantan Selatan Tahun 2008. Loka Litbang P2B2 Tanah Bumbu.

6. Andaruni, A., Sari, F., Bangun, S., 2012. Gambaran Faktor Penyebab Infeksi Cacingan pada Anak di SDN 01 Pasirlangu Cisarua. Fakultas Ilmu Keperawatan UNPAD, Bandung.

7. Pullan, RL., Smith, JL., Jasrasaria R., Brooker SJ. 2014. Global number of infection and disease burder of soil transmitted helminth infection in 2010. Parasit Vectors. 7(37): pp1-19.

8. Ahmed A, Al-Mekhlafi HM, Al-Adhroey AH, Ithoi I, Abdulsalam AM, Surin J. The Nutritional Impacts of Soil-Transmitted Helminths Infections Among Orang Asli Schoolchildren in Rural Malaysia. Parasites \& Vector 2012; 5:119-27.

9. WHO. 2010. Soil-transmitted helminths, Official Website WHO. [cited 2018 July 5]. Available from: URL:https://www.who.int/intestinal_worms/en/

10. Chadijah, S., Sumolang, PPF., Veridiana, NN., 2014. Hubungan Pengetahuan, Perilaku dan Sanitasi Lingkungan dengan Angka Kejadian Kecacingan pada anak sekolah dasar di Kota Palu. Media Litbangkes.24(1):50-56. 
11. Depkes RI. 2006. Surat Keputusan Menteri Kesehatan Nomor 24/MENKES/SK/VI Tentang Pedoman Pengendalian Cacingan. Jakarta: Depkes RI.

12. Yudhastuti, R., Lusno, M.R. 2012 Kebersihan Diri dan Sanitasi Rumah pada Anak Balita dengan Kecacingan. Kesmas National Public Health Journal, 6 (4): 173-178.

13. WHO. 2010. Infant mortality. World Health Organization.

14. Safar R. 2010. Parasitologi kedokteran protozoologi, helmintologi, entomologi. Bandung: Yrama Widya.

15. Widoyono. 2011. Penyakit Tropis : Epidemiologi, Penularan, Pencegahan, dan Pemberantasannya. Jakarta: Erlangga.

16. WHO. 2012. Soil-transmitted helminthiases: eliminating soil-transmitted helminthiases as a public health problem in children : progress report 2001-2010 and strategic plan 2011-2020. Geneva : World Health Organization.

17. Walana, W. et al. Prevalence of hookworm infection: A retrospective study in Kumasi, Ghana. Science Journal of Public Health. 2014; 2(3): 196-9. 